\title{
Parastenocaris hispanica n. sp. (Copepoda: Harpacticoida: Parastenocarididae) from hyporheic groundwaters in Spain and its phylogenetic position within the fontinalis-group of species
}

\author{
Pedro Martínez Arbizu \\ Arbeitsgruppe Zoomorphologie, Fachbereich Biologie, Carl von Ossietzky Universität Oldenburg, \\ D-26111 Oldenburg, Germany
}

Keywords: Harpacticoida, Parastenocaris hispanica, new species, fontinalis-group, Fontinalicaris, taxonomy, phylogeny, zoogeography

\begin{abstract}
Parastenocaris hispanica n. sp. is described from hyporheic groundwaters in Spain. The phylogenetic position of the new species within the fontinalis-group Lang is discussed. As a result $P$. fontinalis meridionalis Rouch is elevated to species rank. The fontinalis-group is characterized by six autapomorphic characters.
\end{abstract}

\section{Resumen}

Se describe una nueva espécie, Parastenocaris hispanica sp. n., de aguas subterráneas de España y se discute su posición filogenética dentro del grupo-fontinalis Lang. Como resultado, $P$. fontinalis meridionalis Rouch debe ser elevado a categoría de espécie. El grupo-fontinalis está caracterizado por seis autapomorfias.

\section{Introduction}

Very little is known about the Parastenocarididae inhabiting the groundwaters of the Iberian Peninsula. Three papers have been published previously: Chappuis (1937) described two new species from caves in Santander (northern Spain), Enckell (1965) found two new species in the river Fuengirola (Andalucia, southern Spain) and Noodt \& Galhano (1969) studied the groundwater fauna of northern Portugal and described five new Parastenocaris species. During an intensive study of the freshwater harpacticoid fauna of the Iberian Peninsula, eight additional Parastenocarididae have been found, four of them new to science. One of these new species belongs to the fontinalis- group (Lang, 1948) and is described here in the first of a series of contributions to the systematics of Iberian Parastenocarididae.

The phylogenetic relationships within the $\mathrm{Pa}$ rastenocarididae are still uncertain. The genus Parastenocaris is without doubt polyphyletic (Schminke, 1993). Discussions about affinities of the known species are based on the assignment of these species to different "phyletic" groups (Lang, 1948). In order to elucidate the phylogenetic position of the newly discovered species, the fontinalis-group is characterized and phylogenetically analysed applying the methods of phylogenetic systematics as defined by Hennig (1982).

\section{Methods}

Groundwater samples were taken by the Karaman-Chappuis method (Chappuis, 1942) in Spanish rivers, filtered through a nylon net of $100 \mu \mathrm{m}$ mesh and preserved in $5 \%$ formaldehyde. Additional samples were kindly made available by Dr. Rouch (Saint-Girons, France). These samples were taken in Spanish rivers by Dr. R. Rouch, Dr. F. Lescher-Moutoué and Dr. N. Gourbault in the years 1976 and 1978. The specimens were transferred to a medium consisting of a mixture of lactic acid and glycerine gelatine and dissected for slide preparation. The figures have been prepared with a Leitz Dialux phase contrast microscope using a camera lucida.

Abbreviations used in the text and figures are: $\mathrm{Al}=$ antennule, $\mathrm{A} 2=$ antenna, ap $=$ apomorphy, $\mathrm{Ae}=$ aesthetasc, $\mathrm{Md}=$ mandible, $\mathrm{Mx1}=$ maxillule, $\mathrm{Mx2}=$ maxilla, $\mathrm{Mxp}=$ maxillipede, $\mathrm{P} 1-\mathrm{P} 6=$ legs 1 to $6, \mathrm{pl}=$ plesiomorphy. 


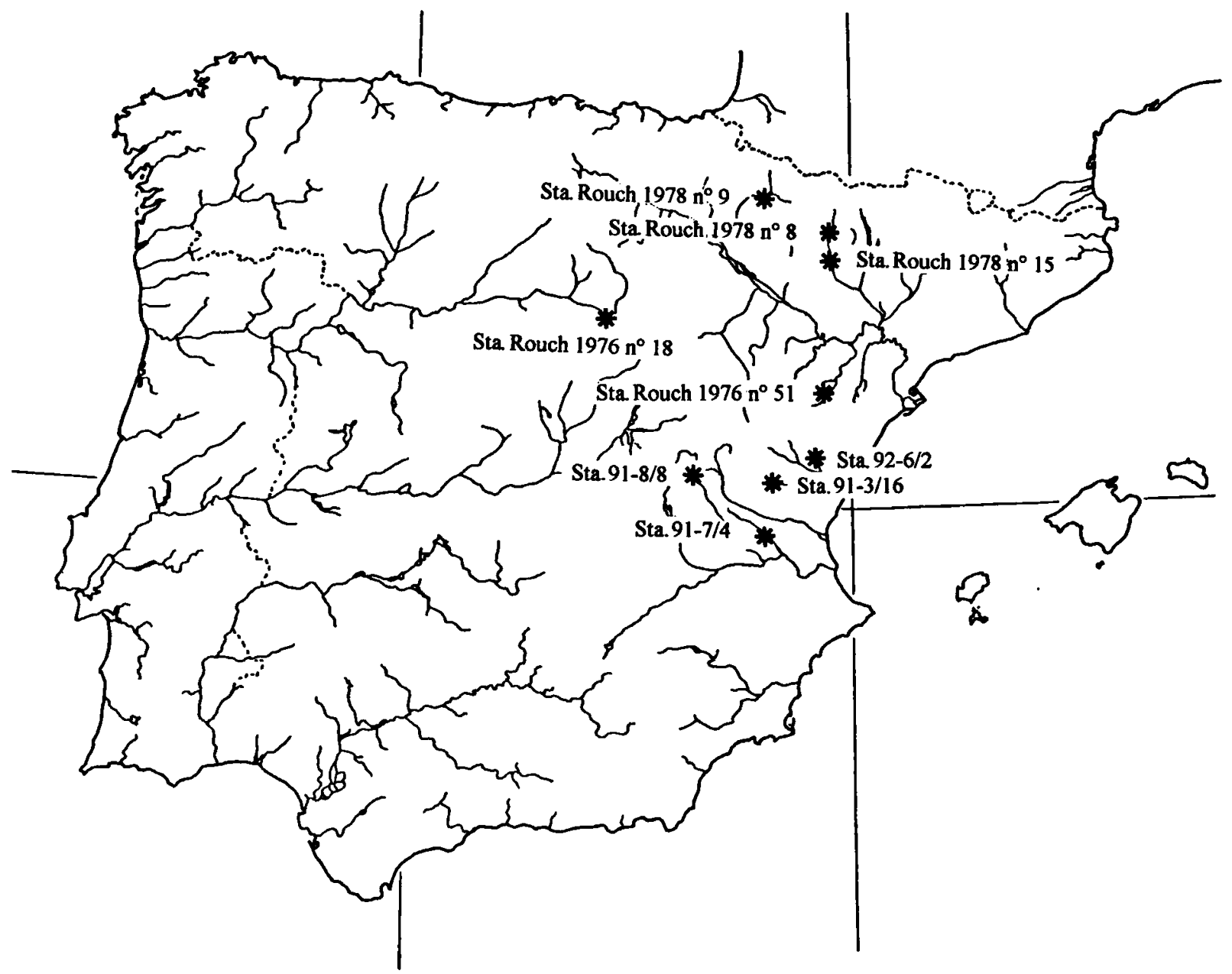

Fig. 1. Map of the Iberian Peninsula with stations where $P$. hispanica $\mathbf{n}$. sp. has been found indicated by an asterisk.

The terms "pars incisiva", "pars molaris", and "lacina mobilis" are omitted from the description of the mandible (Mielke, 1984); the terms "furca" and "telson" are used according to Schminke (1976a); terms of the phylogenetic analysis are used sensu Hennig (1982). The cladogram was made by hand using the so-called "Hennigian principle" (cf. Meier, 1992).

\section{Descriptive part}

Family Parastenocarididae Chappuis, 1933

\section{Parastenocaris hispanica n. sp.}

Material. - Sta. 91-3/16: River Maimona, near bridge at road CS-V-2002, Mas del Molino at Villanueva de Viver (CS), Prov. Teruel, Spain; $4 \mathrm{~m}$ from shore, water temp. $11^{\circ} \mathrm{C}, 8 \sigma^{\circ} \sigma^{\circ}$ and 11 \% ㅇ, 28.3.'91.
Sta. 91-7/4: River Magro, between Macastre and Casas de Millas, Prov. Valencia, Spain; $4 \mathrm{~m}$ from shore, water temp. $22^{\circ} \mathrm{C},>50$ individuals, 10.7.'91.

Sta. 91-8/8: River Cabriel at Las Hondonadas, between El Cañigral and Salvacañete, Prov. Cuenca, Spain (type locality), spring at shore, water temp. $16^{\circ} \mathrm{C}, 150^{\circ} \sigma^{\circ}, 26 \% \&$ and 2 copepodids, 24.8.'91.

Sta. 92-6/2: River Argelita at Fuente de los Ignacios, Argelita, Prov. Castellón, Spain; $1 \mathrm{~m}$ from shore; $>20$ individuals, 15.6.'92.

Sta. Rouch 1976, $\mathrm{n}^{\circ}$ 18: Well between Velamazán and Barca, road Soria-C116, Prov. Soria, Spain; $1 \sigma^{\circ}$ and 1 \&, leg. R. Rouch, 13.9.'76.

Sta. Rouch 1976, $n^{\circ}$ 51: River Guadalope at Mas de las Matas, Prov. Teruel, Spain; $2 \sigma \sigma$ and 1 \&, leg. R. Rouch, 21.9.'76.

Sta. Rouch 1978, $\mathrm{n}^{\circ}$ 9: River Guarga, road C136 at Sabiñánigo, Pito de Momepos, Prov. Huesca, Spain; $2 \sigma^{\circ} \sigma^{\circ}$ and 3 \& \&, leg. R. Rouch, 14.09.'78. 


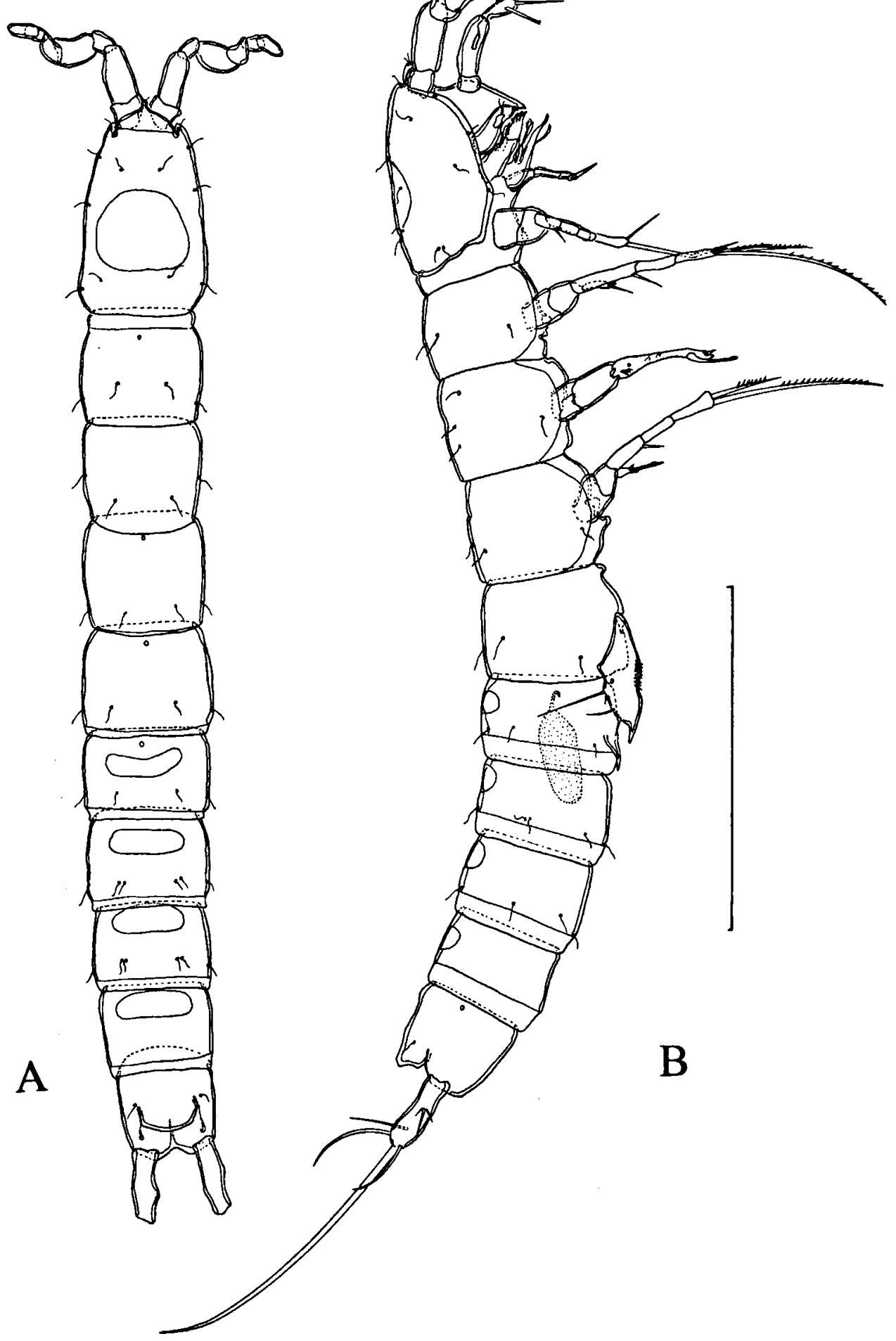

Fig. 2. Parastenocaris hispanica n. sp., male habitus: A, dorsal view; B, lateral view. Scale bar $100 \mu \mathrm{m}$. 


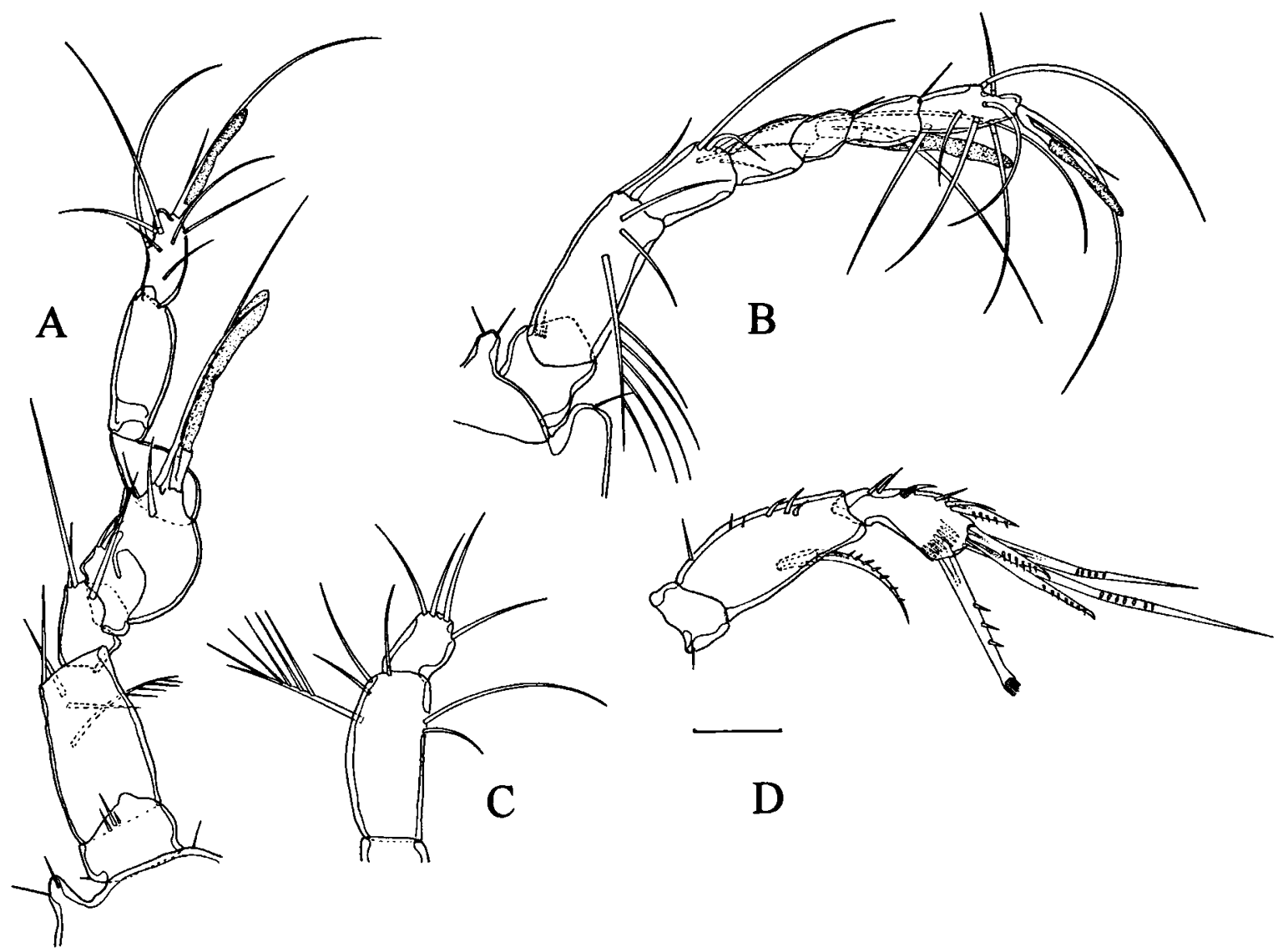

Fig. 3. Parastenocaris hispanica n. sp.: A, male antennule; B, female antennule; C, proximal segments of left male antennule; D, antenna. Scale bar $10 \mu \mathrm{m}$.

Sta. Rouch 1978, n $^{\circ}$ 15: River Alcanadre, road M240 between Angües and Ponzano, Prov. Huesca, Spain; $80^{\circ} \sigma^{\circ}$ and 8 \% \&, leg. R. Rouch, 14.9.'78.

Sta. Rouch 1978, $\mathrm{n}^{\circ}$ 8: River Alcanadre at Bierge, Prov. Huesca, Spain; $1 \circ^{\circ}, 2$ $\%$ and 2 copepodids, leg. R. Rouch, 13.9.'78.

Sta. Rouch 1978 , no 8bis: River Alcanadre at Bierge, Prov. Huesca, Spain; $10^{\circ}$, leg. R. Rouch, 13.9.'78.

The material is stored at the Copepod collection of the Arbeitsgruppe Zoomorphologie, University of Oldenburg, Germany. The type material examined for the description below (from Sta. 91-8/8) consists of 1 dissected o (holotype, Coll. No. 1996.22/1-1996.22/4) and 1 dissected $\%$ (allotype, Coll. No. 1996.23/1-1996.23/4), each mounted on 4 slides.

Distribution. - Northeastern Spain, from the Pyrenees to Valencia, in the river sytems of Ebro, Mijares and Júcar. Also at the river Duero on the Iberian Plateau (Meseta). This river flows into the Atlantic in north Portugal, so that the species may have a wider westerly distribution. Fig. 1 shows the localities where Parastenocaris hispanica $\mathbf{n}$. sp. has been found. The type locality is Sta. 91-8/8, river Cabriel at Salvacañete, Prov. Cuenca, Spain.

Description of holotype and allotype. - Length 380 $\mu \mathrm{m}$ (from rostrum to operculum). Rostrum with large base and two sensillae on tip. Cephalothorax and abdominal segments 1-4 with dorsal "windows" (Fig. 2A). For sensillae on tergites see Fig. 2A-B. Operculum convex (Fig. 6C). Furca (Fig. 7A) with 7 setae, all 3 anterolateral setae located in first third of ramus.

Male: A1 (Fig. 3A, C) 8-segmented, prehensile, number of setae starting at proximal segment: $0 / 6$ / 4/2/4+Ae/0/0/9+Ae. A2 with allobasis and 1-segmented exopod carrying 1 pinnate seta (Fig. 3D). Distal endopod segment with 7 setae ( 2 of them 

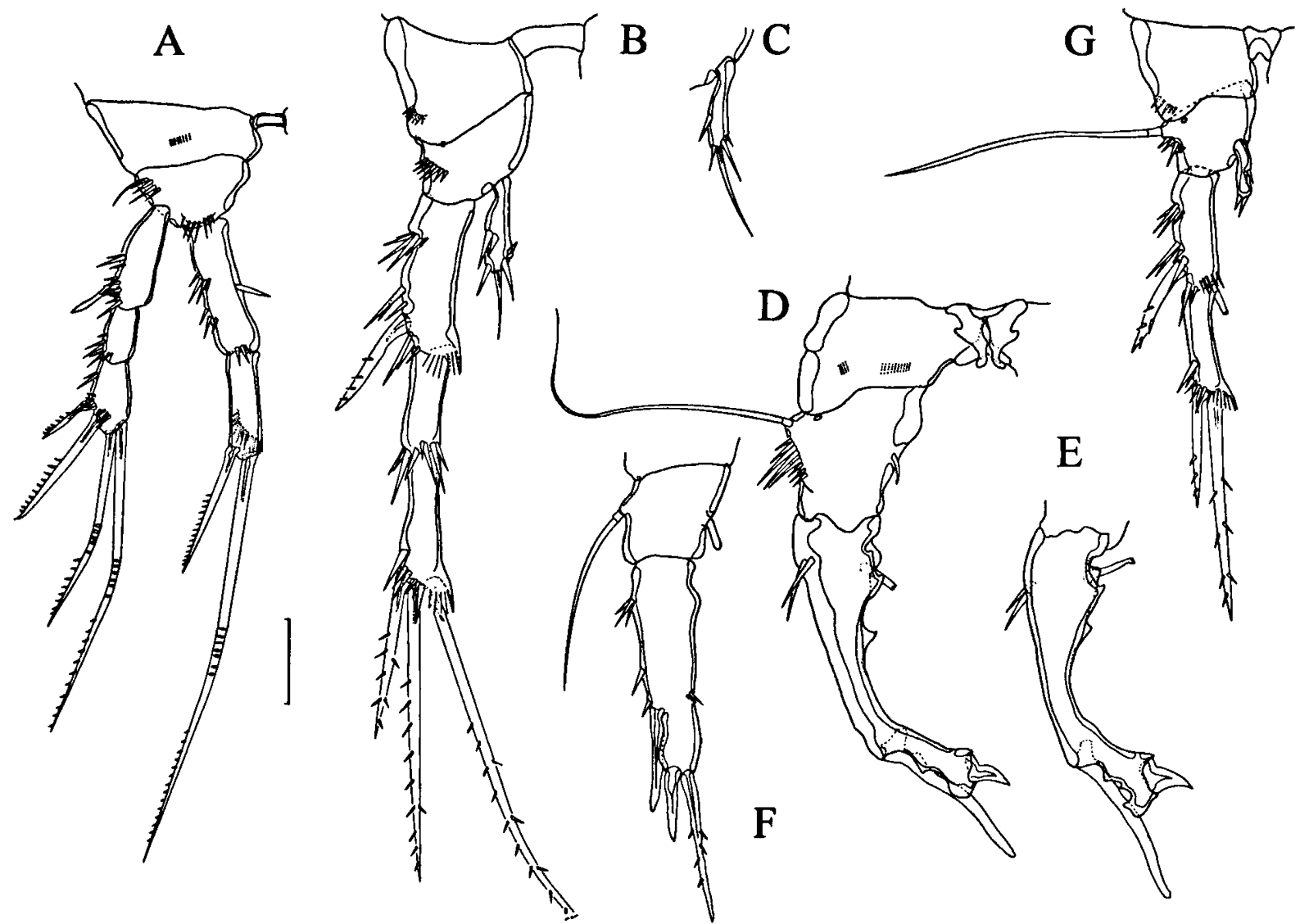

Fig. 4. Parastenocaris hispanica n. sp.: A, male pereiopod 1; B, male pereiopod 2; C, female endopod 2; D, male pereiopod 3; E, male pereiopod 3 from sta. Rouch $1978 \mathrm{n}^{\circ} 8$; F, male pereiopod 3 copepodid V; G, female pereiopod 3 . Scale bar $10 \mu \mathrm{m}$.

geniculate) and hyaline frill. Md with 1-segmented palp (Fig. 6D) carrying 2 setae. Mx1 (Fig. 7D), precoxal arthrite with 5 setae (1 dorsal surface seta, 3 claw-like pinnate setae and 1 slender seta), coxa with 1 seta, basis with 3 setae. Mx2 (Fig. 7C) syncoxa with 2 endites, proximal endite with 1 , distal one with 3 setae, basis with strong apical pinnate claw, endopod represented by 2 setae, exopod absent. Mxp 3-segmented (Fig. 6E), distal segment with 1 seta.

P1 (Fig. 4A) with 3-segmented exopod, segment 2 without setae, segment 3 with 4 setae, endopod of 2 segments, segment 1 with 1 strong inner spine in middle of segment, segment 2 with 2 setae and hyaline frill. P2 (Fig. 4B) with 3-segmented exopod, segments 1 and 3 with hyaline frill, segment 1 without seta, segment 2 without setae, segment 3 with 3 setae, endopod 1-segmented with 1 seta and 6 spinules, outer seta of basis absent. P3 (Fig. 4D) with both exopod segments fused, portion of proximal segment ending in a large seta ("thumb") reaching beyond end of whole exopod, inner margin with protuberances and tube pore reaching beyond inner margin of segment; portion of distal segment ("apophysis") terminally with strong spine (seta), on outer margin with protuberance giving "apophysis" look like a bird finger; endopod represented by 1 seta. P4 (Fig. 5A) with 3-segmented exopod, segment 1 subterminally with row of 8 large and slender spinules on inner margin, segment 2 without setae, segment 3 with 2 apical setae and inner hyaline frill, endopod 1-segmented with terminal seta fused to it and 3 spinules, seta subterminally with 3-4 subordinate spinules fused to its outer margin, basis with hyaline spinule between exopod and endopod, 

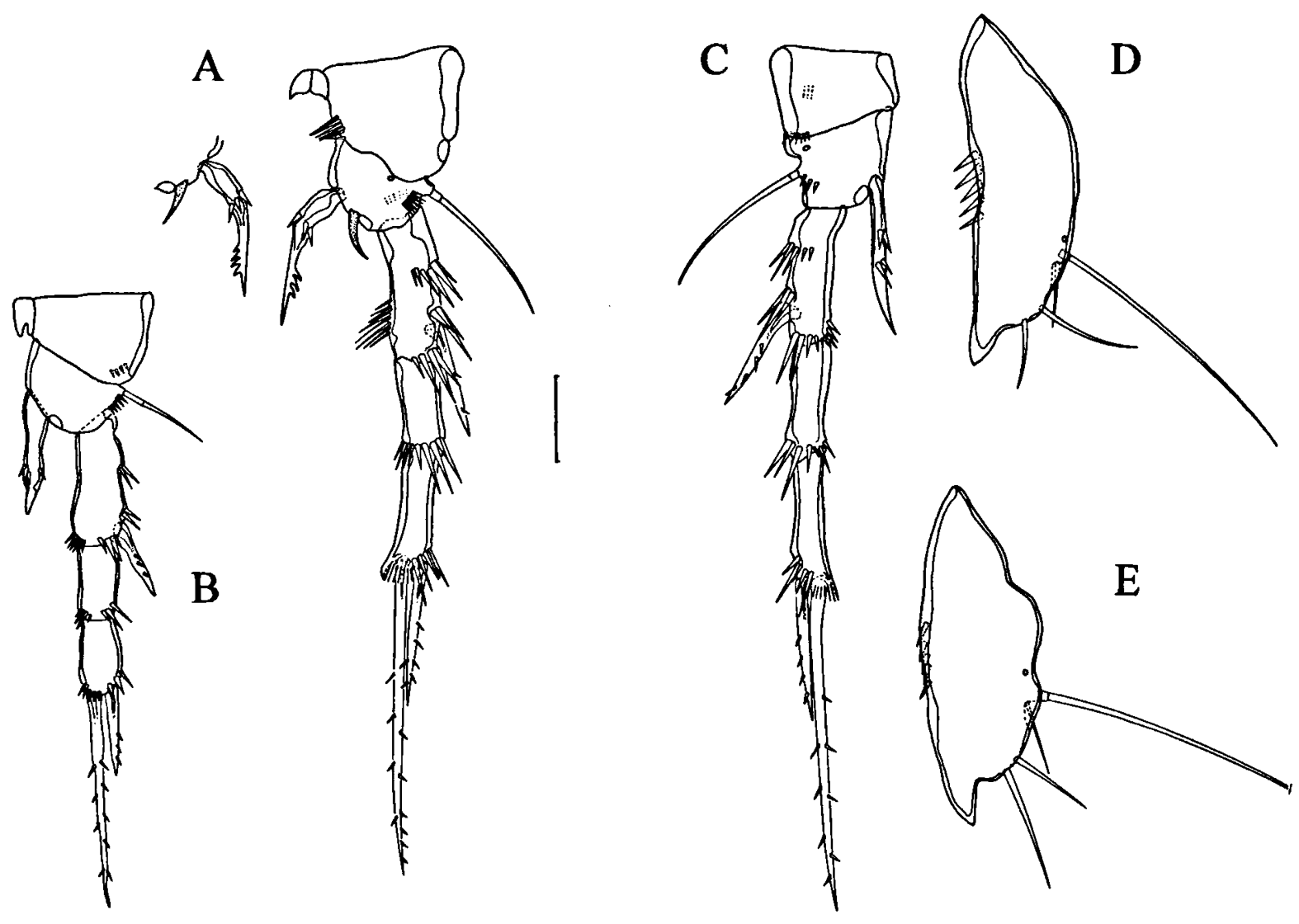

Fig. 5. Parastenocaris hispanica n. sp.: A, male P4 and opposite endopod; B, male pereiopod 4 copepodid V; C, female pereiopod 4; $D$, male pereiopod 5 ventral view; E, male pereiopod 5 lateral view. Scale bar $10 \mu \mathrm{m}$.

coxa with 6 slender spinules on inner margin. P5 (Fig. $5 \mathrm{D}-\mathrm{E}$ ) with convex outer margin bearing 4 setae and inner thorn, and with row of spinules along inner margin.

Female: Sexual dimorphism in A1, P1, P2, P3, P4, P5, and genital field. A1 (Fig. 3B) 7-segmented, not prehensile, number of setae starting at proximal segment: 0/4/5/2+Ae/1/1/9+Ae.

P1 endopod segment 1 with 2 small spinules at inner margin instead of 1 thick spinule. P2 endopod (Fig. 4C) with 1 seta and only 4 spinules. P3 (Fig. 4G) exopod 2-segmented, segment 1 with outer seta, segment 2 with 2 apical setae and inner frill, proximally with tube pore at inner margin, endopod 1-segmented with 4 spinules, without setae. P4 (Fig. 5C) exopod 1 apically with spinules, endopod 1-segmented, with terminal seta without subordinate spinules fused to it, and 4 spinules, basis without hyaline spinule between exopod and endopod, coxa without spinules on inner margin. P5 (Fig. 6A) with only 3 spinules at inner margin. Genital field as illustrated in Fig. $6 \mathrm{~A}$, seminal receptacles dotted.

Derivatio nominis. - The specific name hispanica refers to Spain.

Variability. - Material from Sta. Rouch $1978 n^{\circ} 8$ and Sta. Rouch $1978 \mathrm{n}^{\circ} 8 \mathrm{bis}$ differs from the holotype and allotype in the following characters:

Male: P3 exp (Fig. 4E) "apophysis" with stronger outer protuberance, tube pore orientated upwards. Telson (Fig. 7B) ventrally with 2 strong spinules at base of each furcal ramus.

Female: Furca (Fig. 6B) modified as "bulbifera type" (Noodt, 1963; Schminke, 1991). 


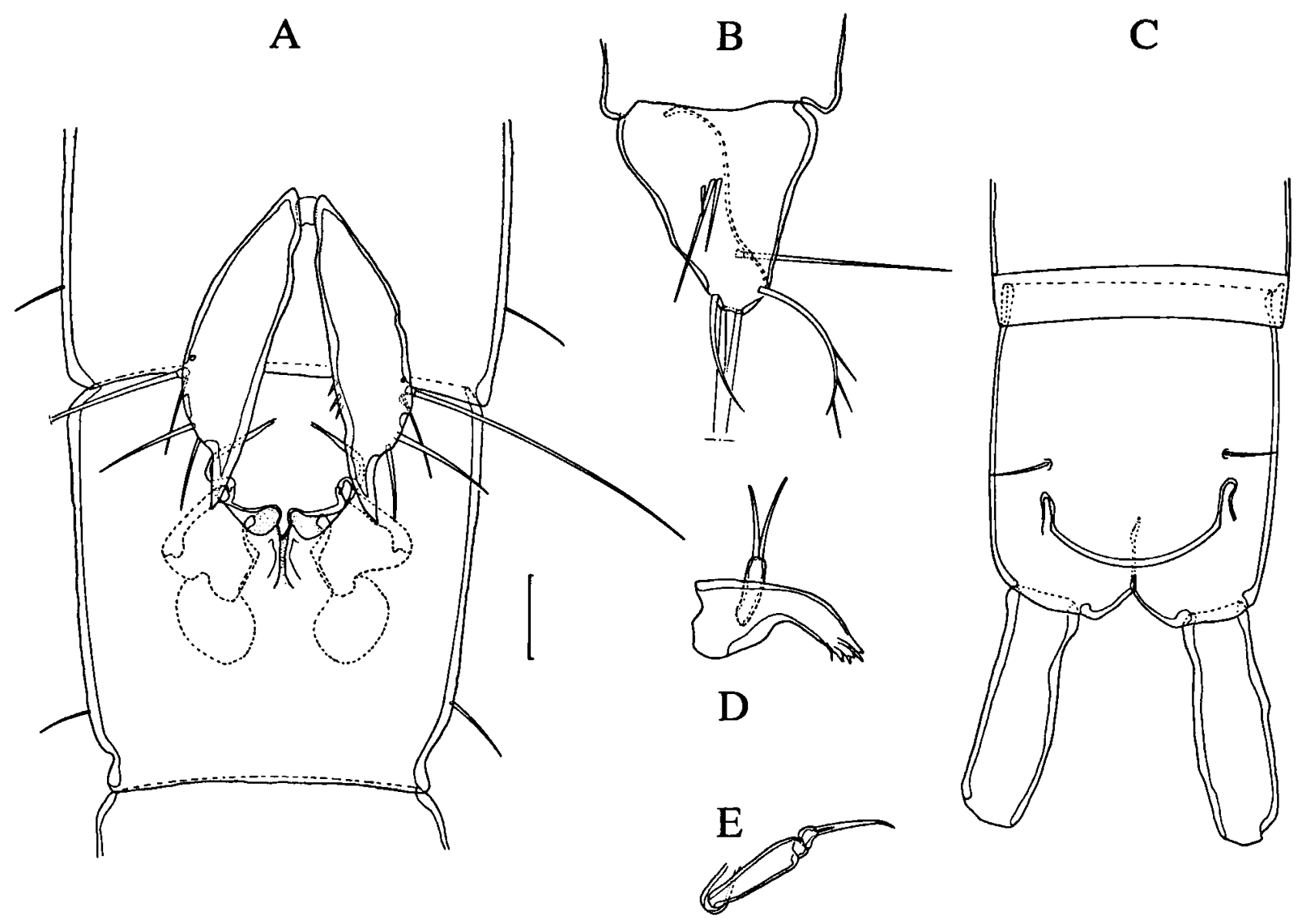

Fig. 6. Parastenocaris hispanica n. sp.: A, female pereiopod 5 and genital field; B, female furca from Sta. Rouch $1978 \mathrm{n}^{\circ} 8$; C, male telson dorsal view; $\mathrm{D}$, mandible; $\mathrm{E}$, maxillipede. Scale bar $10 \mu \mathrm{m}$.

\section{Affinities of Parastenocaris hispanica sp. n.}

The greatest similarities are with those species of the genus belonging to the fontinalis-group (Lang, 1948). Unfortunately, both of Lang's discriminating characters for the fontinalis-group, i.e., "endopod P4 male as female" and "endopod P2 1-segmented", are useless. The endopod P4 of males is different from that of females (see Fig. $5 \mathrm{~A}, \mathrm{C}$; Zinzenco, 1971; Songeur, 1961; Rouch, 1990) even in the species Parastenocaris fontinalis Schnitter \& Chappuis, 1915 (cf. Herzog, 1938). Furthermore, the endopod P2 is 1-segmented in all known Parastenocarididae, this being a symplesiomorphy within the family (cf. Martínez Arbizu \& Moura, 1994).

Lang grouped 5 species together in the fontinalis-group, of which $P$. entzi Török, 1935, $P$. similis Török, 1935, and P. aedes Hertzog, 1938 are not closely related to the nominal species $P$. fontinalis. These three species belong to what Schminke (1993) calls "Parastenocaridinae" in which all three anterolateral setae of the furca insert on its distal third. On the other hand, $P$. fontinalis belongs to what Schminke (1993) calls "Fontinalicaridinae". The fontinalis-group contains $P$. fontinalis fontinalis, $P$. fontinalis borea Kiefer, 1960, $P$. fontinalis meridionalis Rouch, 1990, $P$. aquaeductus Chappuis, 1925, $P$. psammica Songeur, 1961, and $P$. hispanica n. sp. (P. bohemica Sterba, 1968, is a junior synonym of $P$. fontinalis).

All these taxa share the same construction of the male endopod P4 as described above. However, $P$. aquaeductus differs from the other taxa in some important characters: (1) Male P4 endopod fused 


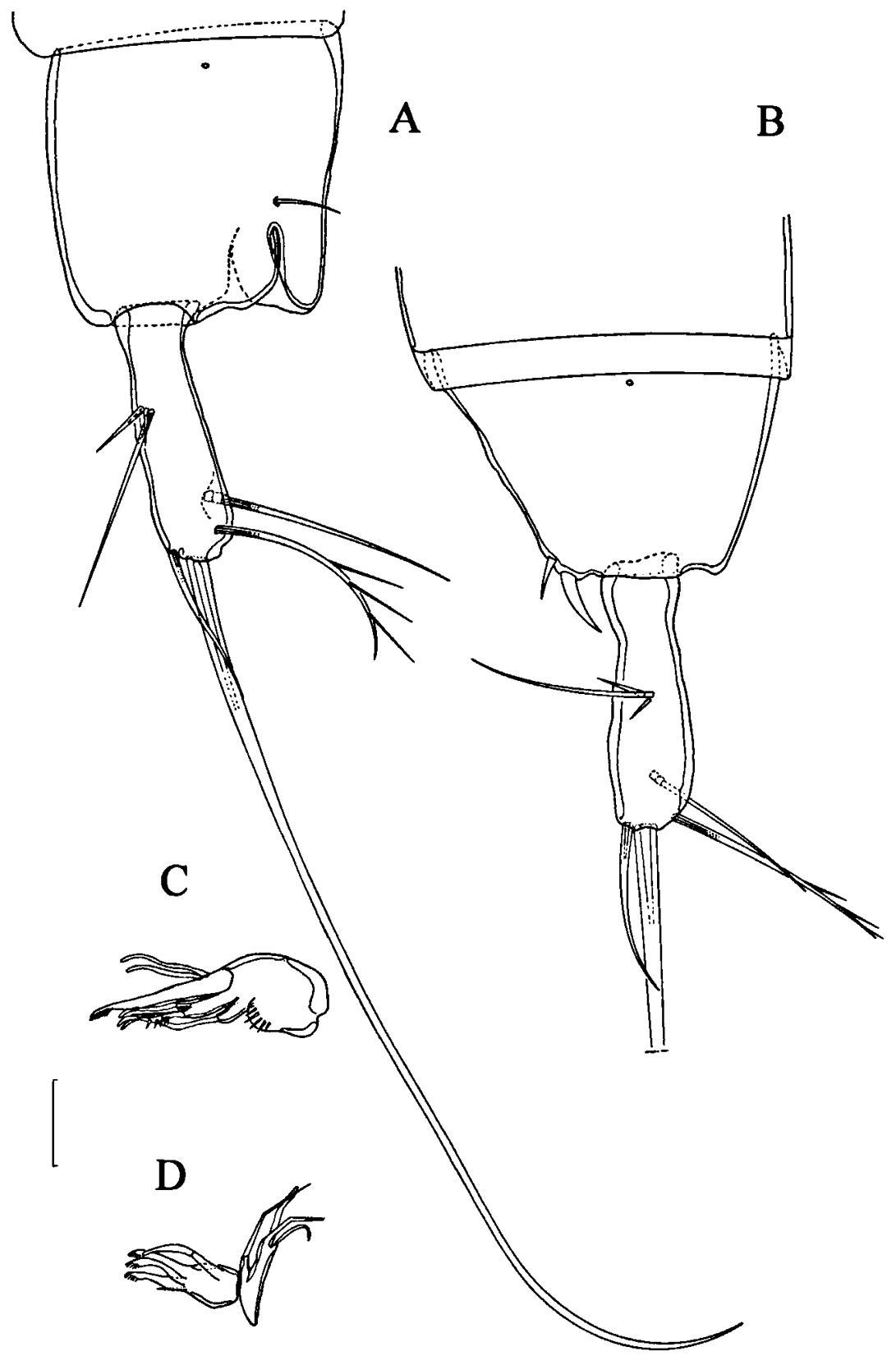

Fig. 7. Parastenocaris hispanica n. sp.: A, male telson lateral view; B, male telson from Sta. Rouch $1978 \mathrm{n}^{\circ} 8$ lateral view; C, maxilla; $\mathrm{D}$, maxillule. Scale bar $10 \mu \mathrm{m}$.

seta with subordinate spinules on both margins, not only on the outer margin. (2) Male P3 basis with a row of spinules on inner margin. (3) Male P3 exopodal portion of segment 1 ends distally on inner margin with 2 little spinules. (4) Male P4 exopodal segment 1 ends distally in a row of spinules on inner margin. (5) Male P3 exopodal "apophysis" as long as wide. (6) Female P4 basis with a row of spinules between exopod and endopod.

Characters 1-6 represent the plesiomorphic state within the fontinalis-group. This allows us to define a well-founded monophyletic group for the remaining species. However, this does not exclude 
Table I. Character matrix.

\begin{tabular}{|c|c|c|c|c|c|c|c|c|c|c|c|c|c|c|c|c|}
\hline Characters & 1 & 2 & 3 & 4 & 5 & 6 & 7 & 8 & 9 & 10 & 11 & 12 & 13 & 14 & 15 & 16 \\
\hline P. hispanica & 1 & 1 & 1 & 1 & 1 & 1 & 0 & $\mathbf{0}$ & 1 & 1 & 0 & 0 & 0 & 0 & 0 & 0 \\
\hline P. meridionalis & 1 & 1 & 1 & 1 & 1 & 1 & 1 & 1 & 0 & 0 & 0 & 0 & 1 & 0 & 0 & 0 \\
\hline P. psammica & 1 & 1 & 1 & 1 & 1 & 1 & 1 & 1 & 0 & 0 & 1 & 1 & 0 & 0 & 1 & 0 \\
\hline$P . f$. fontinalis & 1 & 1 & 1 & 1 & 1 & 1 & 1 & 1 & 0 & 0 & 1 & 1 & 0 & 1 & 0 & 0 \\
\hline P.f. borea & 1 & 1 & 1 & 1 & 1 & 1 & 1 & 1 & 0 & 0 & 1 & 1 & 0 & 1 & 0 & 1 \\
\hline
\end{tabular}

the possibility that another group of species of Parastenocarididae, characterized by an advanced transformation of endopod P4 male, e.g., the group around $P$. kabyloides Enckell, 1969 (Martínez Arbizu, in prep.), may be the sister group of the fontinalis-group excluding $P$. aquaeductus. This species would then be the sister group of a taxon including the fontinalis-group and the group around $P$. kabyloides. For this reason $P$. aquaeductus is excluded from the following phylogenetic discussion, although it is considered an appropriate outgroup to polarize the characters within the fontinalis-group.

\section{Phylogenetic relationships within the fontinalis-group}

Fig. 8 shows the phylogenetic relationships within the fontinalis-group. The different subspecies are treated for this analysis as separate taxa. A character matrix is given in Table I. The characters are listed and polarized as follows:

(1) Male P4 endopod fused seta with subordinate spinules only on outer margin (ap); $P$. aquaeductus and other "Fontinalicaridinae" such as $P$. kabyloides have subordinate spinules on both margins (pl).

(2) Male P3 basis without row of spinules (ap); $P$. aquaeductus, $P$. kabyloides, and most Parastenocarididae have a row of spinules on inner margin of basis of P3 (pl), this being a symplesiomorphy of the family.

(3) Male P3 exopod portion of segment 1 without spinules on inner margin (ap); 2 spinules are present in adult $P$. aquaeductus $(\mathrm{pl})$ and also in the fifth copepodid stage of $P$. hispanica (Fig. 4F), while these spinules get lost with the moult to the adult.

(4) Male P4 exopod 1 row of spinules on inner margin inserting subterminally (ap); these spinules insert terminally (pl) in $P$. aquaeductus and in the fifth copepodid stage of $P$. hispanica (Fig. 5B), being relocated to subterminal position with the adult moult.
(5) Male P3 exopod "apophysis" twice as long as wide (ap); the "apophysis" is as long as wide (pl) in P. aquaeductus and in the fifth copepodid stage of $P$. hispanica (Fig. 4F).

(6) Female P4 basis without any spinules between exopod and endopod (ap); $P$. aquaeductus has a row of spinules at this position (pl).

(7) Male P4 exopod 1 subterminally on inner margin with 4-5 strong spinules (ap); $P$. hispanica has 8 slender spinules $(\mathrm{pl})$. (8) Male P4 coxa with 2-3 strong spinules (ap); $P$. aquaeductus has $5, P$. hispanica has 6 slender spinules $(\mathrm{pl})$.

(9) Male P3 exopod, "apophysis" with a protuberance on outer margin (ap); this protuberance is absent (pl) in P. aquaeductus, $P$. psammica, $P$. f. fontinalis, $P$.f. borea, and $P$. f. meridionalis. (10) Male P3 exopod "apophysis" curved inwardly at an angle of $60^{\circ}$ (ap); $P$. aquaeductus, $P$. psammica, $P$. f. fontinalis, $P . f$. borea, and $P . f$. meridionalis have an angle of $45^{\circ}(\mathrm{pl})$.

(11) Male P5 slender (ap); $P$. aquaeductus, $P$. $f$. meridionalis, and $P$. hispanica have a broad P5 with convex outer margin (pl).

(12) Male P3 "thumb" shorter than "apophysis" (ap); $P$. aquaeductus, $P$. $f$. meridionalis, and $P$. hispanica have a "thumb" longer than "apophysis" (pl).

(13) Female P5 without spinules at inner margin (ap); $P$. aquaeductus, $P$. psammica, $P$. f. fontinalis, $P$. f. borea, and $P$. hispanica have spinules at inner margin (pl).

(14) Operculum triangular (ap); $P$. aquaeductus, $P$. psammica, $P$. f. meridionalis, and $P$. hispanica have a round operculum (pl).

(15) Male P5 inner distal corner with two setae (ap); $P$. aquaeductus, $P$. f. fontinalis, $P$. f. borea, $P$. f. meridionalis, and $P$. hispanica have no setae at this position (pl). No setae are present in the ground pattern of Parastenocarididae (Martinez Arbizu \& Moura, 1994). The acquisition of these 2 setae in $P$. psammica is considered an autapomorphy of this species, this being the most parsimonious assumption.

(16) Male P5 with a strong and large spinule at inner margin (ap); $P$. aquaeductus, $P$. psammica, $P$. f. fontinalis, $P$. $f$. meridionalis, and $P$. hispanica have a row of small spinules at this position (pl).

\section{Biogeography}

The new species has its known distribution in eastern Spain, the Pyrenees being its northern boundary (Fig. 1). On the French (north) side of the Pyr- 


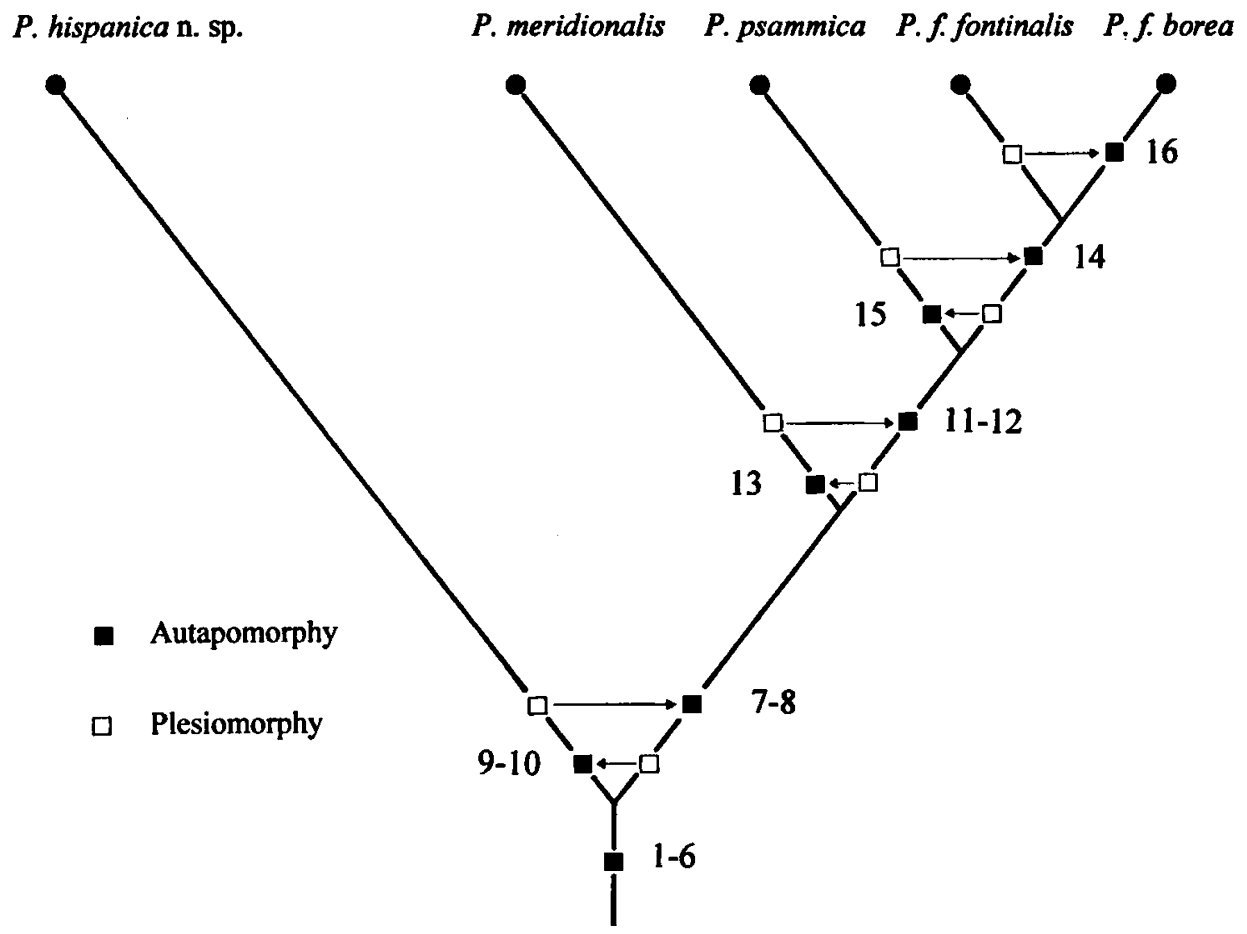

Fig. 8. Phylogenetic position of $P$. hispanica n. sp. Explanation of characters in text.

enees Parastenocaris $f$. meridionalis has been collected at the River Nert (Rouch, 1990), this being the only record of this taxon. Parastenocaris psammica is described from different locations in Lorraine, northern France (Songeur, 1961). The widest distribution has been recorded for Parastenocaris fontinalis, which is present all over Germany, The Netherlands, northern France, Switzerland, and Czechoslovakia (Janetzky et al., 1996), its subspecies $P$. fontinalis borea being distributed in northern Germany and The Netherlands.

A projection of the cladogram on a map showing the approximate distributions of the species of the fontinalis-group shows a high amount of concordance between phylogeny and distribution. The higher the latitude, the relatively more derived the species (Fig. 9). This condition suggests an origin of the fontinalis-group in southwestern Europe and a slow colonization northwards. The first vicariant event is the origin of the Pyrenees isolating the groundwater basins south and north of it. Other vicariant events cannot be explained satisfactorily at the present state of knowledge of the distribu- tion of the French species $P . f$. meridionalis and $P$. psammica. The subspecies $P$. $f$. borea is distributed in groundwaters that where covered with ice during the last glaciation. Assuming the extinction of most groundwater organisms due to the formation of permafrost in the soil during glacial times, we may conclude a colonization of this areas after glaciation by a sub-population of $P$. fontinalis that was better adapted to cold conditions.

\section{Discussion}

The polarization of the characters was done following Hennig's criteria (Hennig, 1982: 98-116) and by outgroup comparison, not only with Parastenocaris aquaeductus, but with all known Parastenocarididae. Only some relevant examples from other taxa were considered in the text to explain the polarization of the characters chosen. In addition, the Hennigian "criterion of ontogenetic character precedence" has been successfully applied to polarize characters 3,4 , and 5 . Some structures 
present in $P$. aquaeductus appear in $P$. hispanica $\mathrm{n}$. sp. during ontogenetic development and are secondarily lost with the final moult to the adult. The polarization of the characters as presented above is also in concordance with the Hennigian "criterion of the correlation of series of transformations" and the "criterion of biogeographic progression". As a result of this analysis, Parastenocaris meridionalis Rouch (syn. P. fontinalis meridionalis Rouch), cannot be considered a subspecies of $P$. fontinalis anymore. It is the sister group of a taxon consisting of $P$. psammica and $P$. fontinalis, that are separate biological species as they are sympatric, having been found together in the same sample (Songeur, 1961). P. meridionalis must therefore be considered a separate species, of which the Pyrenees are the southern distribution limit. $P$. fontinalis borea is further considered a subspecies of $P$. fontinalis.

The phylogenetic relationships of the different species-groups of Parastenocaris are unknown. Jakobi (1972) proposed a new system for the family Parastenocarididae by splitting it into 26 new genera. This artificial system has been strongly criticized by Schminke (1976b) and has not been adopted by Dussart \& Defaye (1990).

One of Jakobi's new genera was Fontinalicaris, having as type species $P$. fontinalis. In this genus, Jakobi included a second species, $P$. phyllophora Noodt, 1954, that is quite unrelated to $P$. fontinalis. A revision of Parastenocaris will result in the recognition of a number of monophyletic groups, one of which will be the genus Fontinalicaris including the species $P$. fontinalis, $P$. psammica, $P$. meridionalis, and $P$. hispanica as is discussed here. Fontinalicaris with its type species Fontinalicaris fontinalis will be the type genus of the subfamily Fontinalicaridinae as advanced by Schminke (1993). Waiting upon this revision, I prefer to use the concept of species-group (in this case fontinalis-group) rather than the genus Fontinalicaris.

\section{Acknowledgements}

I am especially indebted to Dr. Raymond Rouch (C.N.R.S., Saint-Girons, France), who kindly loaned me abundant material for this work. I wish to thank Prof. Dr. H.K. Schminke for his

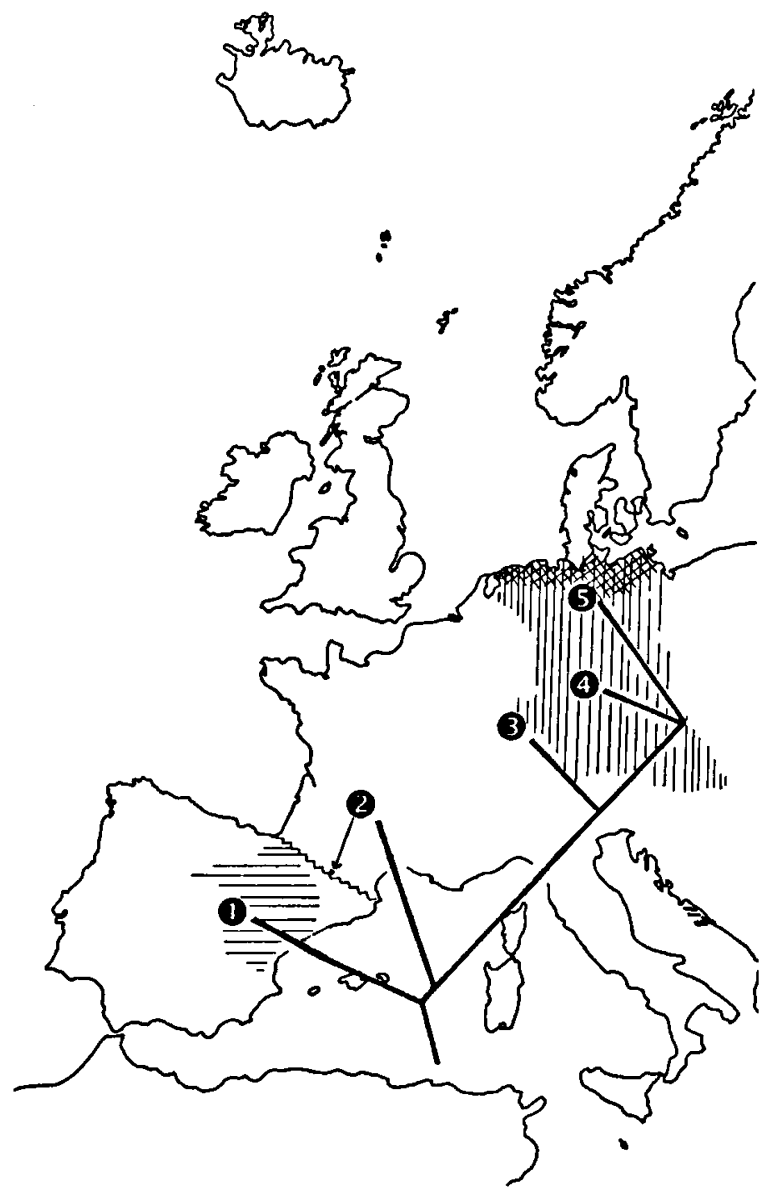

Fig. 9. Projection of the cladogram (Fig. 8) on a map of the western of middle part of Europe showing the distribution of the species belonging to the fontinalis-group. 1, Parastenocaris hispanica n. sp.; 2, P. meridionalis; 3, P. psammica; 4, $P$. fontinalis; $5, P$. f. borea.

unconditional support and continuous discussions especially on parastenocaridid phylogeny. This work has been supported partially by a grant of the Deutscher Akademischer Austauschdienst (D.A.A.D.).

\section{References}

Chappuis, P.A., 1937. Subterrane Harpacticoiden aus NordSpanien. Bull. Soc. Sci. Cluj., 8: 556-571.

Chappuis, P.A., 1942. Eine neue Methode zur Untersuchung der Grundwasserfauna. Acta Scient. Math. Natur. Kolozsvar, 6: 1-17.

Dussart, B. \& D. Defaye, 1990. Répertoire mondial des Crustacés Copépodes des eaux intérieures. III. Harpacticoïdes. Crustaceana, Suppl. 16: 1-384. 
Enckell, P., 1965. New harpacticoids from Spain. Acta Univ. lund., (2) 19: 1-8.

Hennig, W., 1982. Phylogenetische Systematik. Pareys Studientexte, 34: 1-246 (Parey, Berlin/Hamburg).

Herzog, L., 1938. Crustaceen aus unterirdischen Biotopen des Rheintales bei Strassburg. Zool. Anz., 123 (3): 45-56.

Jakobi, H., 1972. Trends (Enp. P4 Männchen) innerhalb der Parastenocarididen (Copepoda, Harpacticoida). Crustaceana, 22: 127-146.

Janetzky, W., R. Enderle \& W. Noodt, 1996. Süßwasserfauna von Mitteleuropa, Bd. 8, Heft 4, Teil 2 (Crustacea, Copepoda, Gelyelloida und Harpacticoida): 1-227 (Gustav Fischer Verlag, Stuttgart).

Lang, K., 1948. Monographie der Harpacticiden I-II: 11682 (Håkan Ohlssons Boktryckeri, Lund).

Martínez Arbizu, P. \& G. Moura, 1994. The phylogenetic position of the Cylindropsyllinae Sars (Copepoda, Harpacticoida) and the systematic status of the Leptopontiinae Lang. Zool. Beitr., (N.F.) 35 (1): 55-77.

Meier, R., 1992. Der Einsatz von Computern in phylogenetischen Analysen - eine Übersicht. Zool. Anz., 229 (3/4): 106-133.

Mielke, W., 1984. Some remarks on the mandible of the Harpacticoida (Copepoda). Crustaceana, 46: 257-260.

Noodt, W., 1963. Subterrane Crustaceen der zentralen Neotropis. Zool. Anz., 117: 114-147.

Noodt, W. \& M.H. Galhano, 1969. Studien an Crustacea sub- terranea (Isopoda, Syncarida, Copepoda) aus dem Norden Portugals. Publicações. Inst. Zool. (Dr. Augusto Nobre), 107: 1-75.

Rouch, R., 1990. Deux nouvelles Parastenocaris (Copépodes, Harpacticoïdes) des Pyrénées. Annls. Limnol., 26 (1): 1928.

Schminke, H.K., 1976a. The ubiquitous telson and the deceptive furca. Crustaceana, 30: 292-300.

Schminke, H.K., 1976b. Systematische Untersuchungen an Grundwasserkrebsen - eine Bestandsaufnahme (mit der Beschreibung zweier neuer Gattungen der Familie Parabathynellidae, Bathynellacea). Int. J. Speleol., 8: 195216.

Schminke, H.K., 1991. Sexual dimorphism in the furcal rami of Parastenocarididae (Copepoda, Harpacticoida). Bull. Plankton Soc. Japan, Spec. vol. (1991): 573-584.

Schminke, H.K., 1993. The subfamilies of the Parastenocarididae. Oral communication at the 5th International Conference on Copepoda, Baltimore (U.S.A.), June 1993.

Songeur, M., 1961. Un nouveau Copépode psammique de Lorraine. Vie Milieu, 12: 483-496.

Zinzenko, D., 1971. Nouvelles données sur la morphologie et la répartition de Parastenocaris aquaeductus Chappuis, 1925 (Copepoda, Harpacticoida). Trav. Inst. Spéol. Emile Racovitza, 10: 179-188.

Accepted: 6 September 1996 